\title{
PENGARUH PERILAKU KEPEMIMPINAN KEPALA SEKOLAH TERHADAP DISIPLIN KERJA GURU
}

\section{THE INFLUENCE OF PRINCIPAL LEADERSHIP BEHAVIOR ON TEACHER WORK DISCIPLINE}

\author{
Moh. Holil, S.Pd, M.Pd \\ SD Negeri Margagiri 2 UPT Dindikbud Kecamatan Pagelaran Pandeglang Banten \\ e-mail:holsthea@gmail.com
}

Diterima: 2 Mei 2017; dikembalikan untuk direvisi: 29 Mei 2017; disetujui: 25 Juli 2017

\begin{abstract}
ABSTRAK
Penelitian ini bertujuan untuk menganalisis pengaruh perilaku kepemimpinan kepala sekolah berorientasi tugas terhadap disiplin kerja guru, menganalisis pengaruh perilaku kepemimpinan kepala sekolah berorientasi hubungan manusia terhadap disiplin kerja guru, dan menganalisis pengaruh perilaku kepemimpinan kepala sekolah berorientasi tugas dan hubungan manusia secara simultan terhadap disiplin kerja guru. Populasi dalam penelitian ini semua guru yang tersebar di semua Sekolah Dasar Negeri di Kecamatan Pagelaran. Pengambilan sampel menggunakan teknik random sampling didapat sebanyak 67 responden. Pengumpulan data menggunakan kuesioner dan analisis menggunakan model persamaan regresi linier ganda. Hasil penelitian diperoleh ada tiga. Pertama, perilaku kepemimpinan berorientasi tugas berpengaruh signifikan dengan sumbangan efektif sebesar 79,50\% terhadap disiplin kerja guru. Kedua, perilaku kepemimpinan berorientasi hubungan manusia berpengaruh signifikan dengan sumbangan efektif sebesar 48,00\% terhadap disiplin kerja guru, Ketiga, secara bersama-sama perilaku kepemimpinan kepala sekolah berorientasi tugas dan hubungan manusia berpengaruh signifikan terhadap dispilin kerja guru, dengan nilai koefisien korelasi $(R)$ sebesar 0,895 dan $R_{\text {square }}\left(R^{2}\right)$ sebesar 0,801 yang berarti bahwa 80,10\% disiplin kerja guru ditentukan oleh perilaku kepemimpinan kepala sekolah berorientasi tugas dan hubungan manusia secara bersama-sama, dan sisanya 19,90\% ditentukan oleh faktor-faktor lain.
\end{abstract}

Kata Kunci : perilaku, kepemimpinan, disiplin kerja

\section{ABSTRACT}

This study aims to analyze the influence of leadership-oriented headmaster behavior toward teacher's work discipline, to analyze the influence ofleadership behavior of headmaster oriented human relationship to teacher work discipline, and to analyze the influence of leadership behavior of headmaster oriented task and human relationship simultaneously to teacher work discipline. Population in this research all teachers spread in all public elementary school in sub-district of Pagelaran. Sampling used is random sampling technique obtained as many as 67 respondents. Data were collected using questionnaire and analysis using multiple linear regression equation model. The results obtained three. First, task-oriented leadership behaviors have significant influence with effective contribution of $79.50 \%$ to teacher work discipline. Second, the behavior of leadership-oriented human relations have a significant effect with the effective contribution of $48.00 \%$ to the discipline of teachers work, Third, together the 
leadership behavior of headmaster task-oriented and human relations have a significant effect on teacher work dispilin, with the value of correlation coefficient $(R)$ of 0.895 and $R$ square (R2) of 0.801 , which means that $80.10 \%$ of the discipline of teachers is determined by the taskheaded leadership behaviors of principals and human relations together, and the remaining $19.90 \%$ is determined by other factors.

Keywords: behavior, leadership, work discipline

\section{PENDAHULUAN}

Pendidikan merupakan ujung tombak kemajuan suatu bangsa. Peran pendidikan yang profesional diperlukan sekali untuk mewujudkan tujuan pendidikan nasional, yakni mencerdaskan kehidupan bangsa dan pengembangan manusia seutuhnya, sesuai dengan Undang-Undang Nomor 20, Tahun 2003 tentang sistem pendidikan nasional, bahwa jabatan guru sebagai pendidik merupakan jabatan profesional (Departemen Pendidikan Nasional, 2003).

Guru merupakan komponen yang paling menentukan dalam sistem pendidikan secara keseluruhan yang harus mendapat perhatian sentral, pertama, dan utama (Mulyasa, 2009: 5). Usaha inovasi pendidikan seperti implementasi pembelajaran dan pembaharuan kurikulum tergantung pada guru. Guru adalah agen terdepan pendidikan. Di tangan guru, pelaksana utama pendidikan, bergantung peningkatan kualitas pendidikan. Kualitas pendidikan ditentukan oleh kualitas guru.

Indikator penting dari kualitas adalah disiplin. Keberadaan disiplin menjadi sangat penting karena memacu pelaksanaan program secara efektif dan menjamin dipatuhinya aturan yang telah ditetapkan. Tata peraturan tersebut menjadi acuan bagi guru dalam melaksanakan tugas pokoknya dan berfungsi menyatukan serta menyelaraskan berbagai tujuan dan tata nilai individual yang dianut.

Kedisiplinan adalah kesadaran seseorang menaati semua peraturan dan norma-norma sosial yang berlaku. Sebagai perwujudan tata aturan berperilaku, disiplin merupakan bagian yang amat penting dan menjadi syarat untuk kemajuan dan keunggulan (Soemarmo, 1998: 26), tak terkecuali dalam bidang pendidikan.

Untuk menunjang semua itu perlu adanya pendukung yang dapat memotivasi disiplin kerja guru di antaranya adalah kepala sekolah, karena Dinas Pendidikan (Mulyasa, 2009:9798) telah menetapkan bahwa kepala sekolah harus mampu melaksanakan pekerjaannya sebagai edukator, manajer, administrator, dan supervisor (EMAS).

Disiplin dimaksudkan bahwa dalam meningkatkan profesionalisme tenaga kependidikan di sekolah kepala sekolah harus berusaha menanamkan disiplin kepada semua bawahannya. Melalui disiplin ini diharapkan dapat tercapai tujuan secara efektif dan efisien, serta dapat meningkatkan produktivitas sekolah (Mulyasa, 2009: 120).

Melalui perilaku kepemimpinan kepala sekolah yang produktif, situasi pembelajaran dapat dilakukan secara efektif, menarik, dan menyenangkan. Hal ini disebabkan karena di tangan kepala sekolah yang kreatif lahir berbagi ide-ide kreatif dalam menggunakan metode dan strategi pembelajaran yang variatif, inovatif, dan menyenangkan bagi peserta didik karena sesuai dengan kebutuhan belajar peserta didik. 
Untuk menegakkan disiplin khususnya guru, Dinas Pendidikan dan Kebudayaan Kabupaten Pandeglang terkadang melakukan inspeksi mendadak (sidak) ke sekolah-sekolah terutama berkaitan dengan kehadiran guru, begitu juga dengan UPT Dinas Pendidikan dan Kebudayaan Kecamatan Pagelaran dan Pengawas Sekolah Kecamatan. Akan tetapi disiplin kerja guru tidak cukup hanya ditingkatkan dengan proses sidak yang lebih otoritatif, sebab disiplin timbul karena ada motivasi baik dari dalam maupun dari luar oleh karena itu motivasi guru untuk disiplin perlu ditanamkan terutama oleh kepala sekolah sebagai pimpinan terdekat dengan guru.

Faktor pendukung dominan bagi kedisiplinan guru berasal dari dalam diri guru sendiri. Faktor-faktor tersebut yaitu kompetensi profesional, motivasi, kreativitas, dan produktivitas guru, pendidikan, serta karakter guru. Bagi guru yang berdisiplin, karena sudah menyatu dalam dirinya maka disiplin bukan lagi merupakan beban, namun sebaliknya membebani dirinya bila tidak berbuat disiplin. Nilai-nilai kepatuhan telah menjadi bagian dari perilaku kesehariannya (Rahayu, dkk, 2014: 98).

Seringkali faktor intern tidak cukup merangsang kedisiplinan guru. Diperlukan faktor luar sebagai motor penggerak yang dirasa cukup kuat sesuai dengan lingkungan kerja dan bidang tugas guru, yaitu kepemimpinan kepala sekolah. Adler (dalam Permadi, 2011:24) menegaskan "The quality of teaching and learning that goes in a school is largely determined by the quality of principals leadership." Kualitas pengajaran dan pembelajaran yang berlangsung di sekolah sangat ditentukan oleh kualitas kepemimpinan kepala sekolah.
Sebagai pemimpin di sekolah, kepala sekolah hendaknya menerapkan perilaku yang dapat membangkitkan gairah kerja para staf khususnya guru. Hal ini sesuai dengan pendapat Mulyasa (2009: 107) yang menyebutkan perilaku kepemimpinan kepala sekolah harus mendorong kinerja para guru dengan menunjukan rasa bersahabat, dekat dan penuh pertimbangan terhadap guru, baik secara individu maupun kelompok.

Menurut penelitian dari Universitas Michigan (dalam Gibson, et al. 1988: 268269) "Berpusat pada Pekerjaan dan Berpusat pada Karyawan" penelitian dilakukan dalam berbagai macam jenis industri dan badanbadan pemerintahan. Lewat wawancara dengan pemimpin dan pengikut, para ahli riset mengidentifikasi dua gaya kepemimpinan yang berbeda-beda yang dinamakan berpusat pada pekerjaan (job-centered) dan berpusat pada karyawan (employee-centered). Produktivitas naik pada kedua sistem, dengan kenaikan 25 persen dalam divisi yang dikendalikan secara hirarkis dan 20 persen dalam divisi yang partisipatif. Kenaikan ini dicapai dengan prosedur yang berbeda-beda dalam dua sistem tersebut. Dalam divisi yang dikendalikan secara hirarkis, diasumsikan bahwa tekanan dan perilaku pemimpin yang berpusat pada pekerjaan merupakan sebab kenaikan. Namun, dalam divisi partisipatif karyawan itu sendiri mengurangi jumlah tenaga kerja dan mengembangkan beberapa prosedur.

Hasil penelitian Rahayu dkk (2014) dengan judul "Kepemimpinan Kepala Sekolah dan Kedisiplinan Guru SMPN Kota Surakarta“ menunjukkan bahwa ada kontribusi secara positif dan signifikan kompetensi profesional, motivasi, dan persepsi guru tentang 
kepemimpinan kepala sekolah terhadap kedisiplinan guru. Besar kontribusi secara simultan 77,1\%. Kepala sekolah mampu menjelaskan keragaman total dari kinerja guru sebesar 77,1\%. Kontribusi persepsi guru tentang kepemimpinan kepala sekolah sebesar $11,09 \%$ terhadap kedisiplinan guru.

Penelitian Faruq (2006) tentang "Perilaku Kepala Sekolah dalam Meningkatkan Profesionalisme Guru di SMA Khadijah Surabaya" menunjukkan bahwa secara khusus perilaku Kepala Sekolah SMA Khadijah Surabaya, yaitu perilaku yang berorientasi pada tugas dan perilaku yang berorientasi pada hubungan manusia, tercermin antara lain pada proses pemberian tugas seperti mengatur dan merumuskan peran anggotanya, menciptakan jalur komunikasi dan hubungan manusia seperti memelihara hubungan yang harmonis dengan siapa saja dan memberdayakan semua komponen sekolah secara sama, baik guru ataupun karyawan, dan memandang mereka sebagai rekan kerja bukan hubungan atasan bawahan.

Penelitian Ali (2007) tentang "Pengaruh Perilaku Kepemimpinan Kepala Sekolah terhadap Disiplin Kerja Guru SDN di Kabupaten Sampang", menunjukan bahwa: (1) terdapat hubungan yang signifikan antara perilaku kepemimpinan kepala sekolah berorientasi pada tugas dengan disiplin kerja guru, (2) terdapat hubungan signifikan antara perilaku kepemimpinan kepala sekolah berorientasi pada hubungan antarmanusia dengan disiplin kerja guru, (3) terdapat hubungan yang signifikan antara perilaku kepemimpinan kepala sekolah berorientasi pada tugas dan berorientasi pada hubungan antarmanusia secara bersama-sama dengan disiplin kerja guru.
Penelitian Murtadlo (2008) tentang "Pengaruh Kepemimpinan Kepala Sekolah terhadap Displin Kerja Guru SD di Kecamatan Sumobito" menunjukkan bahwa: (1) terdapat pengaruh yang signifikan antara perilaku kepemimpinan kepala sekolah SD yang berorientasi tugas terhadap disiplin kerja guru dengan koefeisien korelasi sebesar 0.364 dan besarnya pengaruh sebesar $13,2 \%$, (2) terdapat pengaruh yang signifikan antara perilaku kepemimpinan kepala sekolah SD yang berorientasi hubungan antarmanusia dengan disiplin kerja guru dengan koeifisien korelasi sebesar 0,220 dengan besar pengaruh $4,8 \%$, (3) terdapat pengaruh yang signifikan antara perilaku kepemimpinan kepala sekolah berorientasi pada tugas dan berorientasi pada hubungan antarmanusia secara bersama-sama dengan disiplin kerja guru dengan koefisien korelasi bersama sebesar 0,367 dengan besarnya pengaruh $13,5 \%$.

Penelitian Walker (2009) tentang "The Impact of Principal Leadership Behaviors on the Efficacy of New and Experienced Middle School Teachers" menunjukkan bahwa keberhasilan guru secara signifikan dipengaruhi oleh perilaku kepala sekolah berdasarkan pengalaman guru lama mengajar, sedangkan guru baru diperlukan lebih banyak dukungan dan contoh perilaku yang baik dari kepala sekolah mereka, supaya guru lebih berpengalaman dipengaruhi oleh faktor emosional seperti inspirasi dan tujuan.

Penelitian Sudharto (2012) tentang "Pengaruh Pola Kepemimpinan Kepala Sekolah dan Suasana Kerja Terhadap Kinerja Guru" menunjukkan bahwa menurut persepsi guru: (1) ada pengaruh yang signifikan pola kepemimpinan kepala sekolah terhadap kinerja guru, (2) ada pengaruh yang signifikan 
suasana kerja terhadap kinerja guru, (3) secara bersama-sama ada pengaruh yang signifikan pola kepemimpinan kepala sekolah dan suasana kerja terhadap kinerja guru.

Penelitian Terek (2015) tentang "The Impact of Leadership on the Communication Satisfaction of Primary School Teachers in Serbia" menunjukkan adanya efek kepemimpinan pada kepuasan komunikasi guru. Data tersebut diperoleh dengan memberikan kuesioner kepada 362 guru dari 57 sekolah dasar di Serbia. Kepemimpinan terbukti memiliki dampak yang kuat dan positif pada kepuasan komunikasi guru di sekolah dasar Serbia. Hal yang utama kepala sekolah di Serbia harus mencurahkan perhatian yang cukup besar untuk mengembangkan kepemimpinan dan keterampilan komunikasi. Ini akan berpengaruh untuk mencapai peningkatan komunikasi dan kepuasan kerja di kalangan guru, yang berpotensi menciptakan kondisi untuk meningkatkan dan efektif fungsi sekolah.

Penelitian Hidayat (2007) tentang "Pengaruh Perilaku Kepemimpinan dan Budaya Organisasi terhadap Kinerja Guru SMU Negeri di Kota Surabaya". menunjukkan bahwa perilaku kepemimpinan dan budaya organisasi dapat mempengaruhi kinerja guru sebesar 28,6\%. Artinya, perilaku kepemimpinan dan budaya organisasi besar pengaruhnya terhadap kinerja guru.

Penelitian Hafidz (2003) tentang "Perilaku Kepemimpinan Kepala Sekolah (Studi kasus di SD Ta'miriyah Surabaya)" menunjukan secara khusus perilaku pemimpin di Sekolah Dasar Ta'miriyah yaitu perilaku yang mempunyai orientasi tugas dan perilaku yang mempunyai orientasi pada hubungan manusia, yang tercermin antara lain pada prinsip-prinsip tugas seperti mengatur dan merumuskan peran anggotanya, menciptakan jalur komunikasi dan hubungan manusia seperti memelihara hubungan yang harmonis dengan siapa saja dan memperlakukan semua komponen sekolah sama, baik guru, ataupun karyawan sekolah, dan memandang mereka sebagai rekan kerja bukan hubungan atasan dengan bawahan

Berdasarkan penelitian di atas maka dikaji apakah ada pengaruh perilaku kepemimpinan kepala sekolah SD Negeri di Kecamatan Pagelaran terhadap disiplin kerja guru, karena dengan disiplin yang baik akan meningkatkan kualitas dan produktivitas kerja di lembaga pendidikan, yang tentunya akan berdampak pada kualitas pendidikan di sekolah.

Berdasarkan pengamatan di lapangan yang ditemui beberapa guru kurang disiplin dan terkena sidak bukan karena semata-mata kesalahan mutlak mereka sendiri, tetapi ada di antaranya karena kepala sekolah kurang tegas, kurang berperilaku baik, dan kurang transparan (open management) serta kurang memperhatikan sisi hubungan manusia. Hal ini berarti adanya hubungan perilaku kepemimpinan kepala sekolah terhadap disiplin kerja guru.

Perilaku kepemimpinan kepala sekolah di Kecamatan Pagelaran Pandeglang tentu berbeda-beda. Berdasarkan pengamatan di lapangan ada perilaku pimpinan yang memang hanya menekankan pada tugas, cenderung kaku, sesuai aturan, dan mengabaikan hubungan manusia. Namun, ada juga yang mempunyai hubungan manusia yang baik menekankan kebersamaan, terbuka dan transparan, serta ada juga yang kedua-duanya menekankan pada tugas dan mempunyai hubungan manusia yang baik. 
Sebenarnya perilaku-perilaku kepemimpinan di atas merupakan perilaku kepemimpinan efektif yang tujuannya baik untuk kedisiplinan para guru. Namun, dari perilaku itu ada yang memacu disiplin atau malah sebaliknya. Hal ini memberikan tanggapan dan pengaruh yang berbeda-beda terhadap kedisiplinan kerja guru.

Dari masalah di atas maka yang dikaji dan dianalisis dalam penelitian ini dirumuskan sebagai berikut: 1) Adakah pengaruh perilaku kepemimpinan kepala sekolah yang berorientasi pada tugas terhadap disiplin kerja guru? 2) Adakah pengaruh perilaku kepemimpinan kepala sekolah yang berorientasi pada hubungan manusia terhadap disiplin kerja guru? 3) Adakah pengaruh perilaku kepemimpinan kepala sekolah yang berorientasi pada tugas dan berorientasi pada hubungan manusia secara bersama-sama terhadap disiplin kerja guru?

Tujuan dari penelitian ini adalah untuk menganalisis pengaruh perilaku kepemimpinan kepala sekolah berorientasi tugas terhadap disiplin kerja guru, menganalisis pengaruh perilaku kepemimpinan kepala sekolah berorientasi hubungan manusia terhadap disiplin kerja guru, dan menganalisis pengaruh perilaku kepemimpinan kepala sekolah berorientasi tugas dan berorientasi hubungan manusia secara simultan terhadap disiplin kerja guru.

\section{KAJIAN PUSTAKA}

\section{Perilaku Kepemimpinan Berorientasi Tugas}

Ada beberapa definisi tentang kepemimpinan yang berorientasi pada tugas, di antaranya adalah Pidarta (2005:196) yang menyebutkan bahwa kepemimpinan yang berorientasi pada tugas ialah pemimpin yang hanya menekankan penyelesaian tugas-tugas kepada bawahannya dengan tidak memperdulikan perkembangan bakat, kompetensi, motivasi, minat, komunikasi, dan kesejahteraan bawahan.

Menurut Stoner dan Freman (1994: 165) manajer (pimpinan) yang memiliki gaya berorientasi tugas, mengawasi anggota organisasinya (karyawan) secara ketat untuk memastikan tugas-tugas dilaksanakan secara memuaskan. Pelaksanaan tugas lebih diutamakan daripada pertumbuhan dan kepuasan pribadi anggota organisasi.

Definisi lain tentang kepemimpinan berorientasi tugas menurut Toha (2004: 77) menyebutkan bahwa perilaku tugas ialah suatu perilaku seorang pimpinan untuk mengantar dan merumuskan perananperanan dari anggota kelompok atau para pengikut, menerangkan kegiatan yang harus dikerjakan oleh masing-masing anggota, kapan dilakukan, di mana melaksanakannya, dan bagaimana tugas-tugas itu harus dicapai.

Yukl (2009: 79) menyebutkan berorientasi pada tugas adalah jenis perilaku terutama memperhatikan penyelesaian tugas, menggunakan personil dan sumber daya secara efisien, dan menyelenggarakan operasi yang teratur dan dapat diandalkan.

Berdasarkan beberapa definisi di atas dapat disimpulkan bahwa pada dasarnya perilaku kepemimpinan yang berorientasi pada tugas adalah perilaku yang diterapkan seorang pemimpin yang hanya menekankan pada tugas-tugas dari bawahannya tanpa mempedulikan perkembangan bakat, kompetensi, motivasi, minat, komunikasi dan kesejahteraan bawahan sehingga lebih bersifat otoritatif untuk mencapai tujuan. 
Indikator kepimpinanan berorientasi pada tugas adalah menjelaskan, memantau, tanggung jawab, dan menginformasikan.

\section{Perilaku Kepemimpinan Berorientasi pada Hubungan antarmanusia}

Ada beberapa definisi tentang perilaku kepemimpinan yang berorientasi pada hubungan antarmanusia, di antaranya menurut Pidarta (2005:196) kepemimpinan yang berorientasi pada antarhubungan manusia hanya menekankan perkembangan para personalianya, kepuasan mereka, motivasi, kerja sama, pergaulan dan kesejahteraan mereka. Yang penting baginya adalah nasib para bawahan, tentang kepentingan organisasi adalah nomor dua. Pemimpin ini berasumsi bila para personalia diperhatikan perkembangan dan nasibnya otomatis tujuan organisasi pendidikan akan tercapai.

Menurut Toha (2004:77) perilaku hubungan ialah perilaku seorang pimpinan yang ingin memelihara hubungan-hubungan antarpribadi di antara dirinya dengan anggotaanggota kelompok atau para pengikut dengan cara membuka lebar-lebar jalur komunikasi, mendelegasikan tanggung jawab, dan memberikan kesempatan pada bawahan untuk menggunakan potensinya. Hal semacam ini disifati oleh dukungan sosioemosional, kesetiakawanan, dan kepercayaan bersama.

Berorientasi hubungan, jenis perilaku ini terutama memperhatikan perbaikan hubungan dan membantu orang, meningkatkan kooperasi dan kerja tim, meningkatkan kepuasan kerja bawahan, dan membangun identifikasi dengan bawahan (Yukl 2009:79).

Stoner (dalam Wahyudi, 2009: 70) menjelaskan bahwa hubungan manusia adalah cara manajer berhubungan dengan bawahannya, kalau karyawan bekerja lebih giat, itu berarti organisasi mempunyai hubungan manusia yang efektif, sebaliknya kalau karyawan malas bekerja dan terjadi penurunan semangat kerja maka hubungan antarmanusia dalam organisasi tidak efektif.

Berdasarkan beberapa definisi para ahli di atas, disimpulkan bahwa perilaku kepemimpinan yang berorientasi pada hubungan antarmanusia menekankan pada komunikasi serta membangun dan mempertahankan hubungan yang efektif seperti motivasi, peningkatan kesejahteraan, dan kepuasan para staf/pegawai sehingga tujuan organisasi dapat tercapai. Indikator perilaku kepimpinanan berorientasi hubungan antarmanusia adalah memberi dukungan, mengembangkan, memberi pengakuan, komunikasi, dan kerja sama.

\section{Disiplin Kerja Guru}

Menurut The Liang Gie (dalam Saondi dan Suherman, 2015:40) disiplin adalah suatu keadaan tertib di mana orang-orang yang tergabung dalam suatu organisasi tunduk pada peraturan-peraturan yang telah ada dengan rasa senang.

Singodimedjo (dalam Sutrisno, 2012: 86) mengatakan disiplin adalah sikap kesediaan dan kerelaan seseorang untuk mematuhi dan menaati norma-norma peraturan yang berlaku di sekitarnya. Disiplin karyawan yang baik akan mempercepat tujuan perusahaan, sedangkan disiplin yang merosot akan menjadi penghalang dan memperlambat pencapaian tujuan perusahaan. Disiplin sangat diperlukan baik individu yang bersangkutan maupun oleh organisasi (Sutrisno, 2012:86).

Pidarta (1995:64) menyebutkan disiplin adalah tata kerja seseorang yang sesuai dengan aturan dan norma yang telah disepakati 
sebelumnya. Menurut Nawawi (2003: 330) disiplin kerja merupakan kondisi organisasi atau iklim kerja yang sangat penting dalam kepemimpinan untuk mengefektifkan organisasi. Tanpa disiplin kerja akan sulit mewujudkan efektivitas dan efisiensi kerja, sehingga akan sulit pula dalam mencapai tujuan organisasi secara maksimal.

Sehubungan dengan itu Theo Haiman (dalam Nawawi, 2003: 330) mengatakan bahwa disipillin adalah suatu kondisi yang tertib, dengan anggota organisasi yang berperilaku sepantasnya dan memandang peraturan-peraturan organisasi sebagai perilaku yang dapat diterima. Disiplin dikatakan baik apabila karyawan/anggota organisasi secara umum mengikuti aturanaturan organisasi, dan dikatakan buruk apabila tidak mengikuti atau melanggar aturan-aturan tersebut.

Definisi lain tentang disiplin menurut Mulyasa (2004: 118) menyebutkan disiplin merupakan sesuatu yang penting untuk menanamkan rasa hormat terhadap kewenangan, menanamkan kerja sama, dan merupakan kebutuhan untuk berorganisasi, serta untuk menanamkan rasa hormat terhadap orang lain.

Dikaitkan dengan disiplin guru menurut Indrafachrudi (1994: 36) menyebutkan bahwa guru yang berdisiplin adalah guru yang memahami tujuan pendidikan yang jelas dan memiliki motivasi untuk mencapainya dengan jalan bekerja keras.

Berdasarkan uraian beberapa pokok pikiran di atas, disimpulkan bahwa disiplin kerja guru adalah suatu ketertiban seorang guru dengan menunjukan perilaku yang sesuai dengan peraturan-peraturan yang berlaku di sekolah serta menanamkan kerja sama, motivasi, serta rasa hormat terhadap kewenangan dan orang lain dalam melaksanakan tugas dan fungsinya untuk mencapai tujuan sekolah.

Dengan demikian, kedisiplinan seorang guru menjadi tuntutan yang sangat penting untuk dimiliki dalam upaya menunjang dan meningkatkan kinerja dan sisi lain akan memberikan teladan bagi siswa bahwa disiplin sangat penting bagi siapa pun apabila ingin sukses. Adapun indikator disiplin kerja guru adalah disiplin pada aturan dan tata tertib, disiplin terhadap perintah atasan, disiplin terhadap waktu, dan disiplin terhadap hubungan orang lain.

\section{Hipotesis Penelitian}

Berdasarkan kajian teori dan kerangka berpikir yang telah dikemukakan dapat dirumuskan hipotesis penelitian sebagai berikut: 1) Terdapat pengaruh perilaku kepemimpinan kepala sekolah yang berorientasi pada tugas terhadap disiplin kerja guru, 2) Terdapat pengaruh perilaku kepemimpinan kepala sekolah yang berorientasi pada hubungan manusia terhadap disiplin kerja guru, dan 3) Terdapat pengaruh yang signifikan perilaku kepemimpinan kepala sekolah yang berorientasi pada tugas dan berorientasi pada hubungan manusia secara bersama-sama terhadap disiplin kerja guru.

\section{METODE PENELITIAN}

Dalam penelitian ini variabel perilaku kepemimpinan kepala sekolah berorientasi pada tugas dan perilaku kepemimpinan kepala sekolah berorientasi pada hubungan manusia sebagai variabel bebas yang akan diteliti pengaruhnya terhadap variabel terikatnya, yaitu disiplin kerja guru. Adapun rancangan 
penelitian ini adalah sebagai berikut:

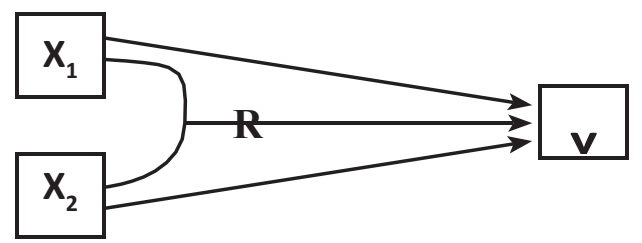

Keterangan:

$\mathrm{X}_{1}=$ Perilaku Kepemimpinan Kepala

Sekolah Berorientasi Tugas

$\mathrm{X}_{2}=$ Perilaku Kepemimpinan Kepala

Sekolah Berorientasi Hubungan

$\mathrm{Y}=$ Disiplin Kerja Guru

$\mathrm{R}=$ Korelasi Ganda

Populasi dalam penelitian ini berjumlah semua guru pada Sekolah Dasar Negeri di Kecamatan Pagelaran. Sampel diambil sebanyak 67 responden guru dengan random sampling menggunakan rumus Taro Yamane atau Slovin (dalam Riduwan, 2014: 65) sebagai berikut:

$$
n=\frac{N}{N \cdot \mathrm{d}^{2}+1}
$$

\section{Keterangan}

$\mathrm{n}=$ Jumlah Sampel

$\mathrm{N}=$ Jumlah populasi 207 responden

$\mathrm{d}^{2}=$ Presisi (ditetapkan 10\% dengan tingkat kepercayaan 95\%)

Teknik pengumpulan data dengan menggunakan kuesioner. Dalam kuesioner ini terdapat 64 pernyataan menggunakan skala likert 1-4 dengan rincian 20 pernyataan dengan 5 indikator perilaku kepemimpinan kepala sekolah berorientasi tugas, 24 pernyataan dengan 5 indikator perilaku kepemimpinan kepala sekolah berorientasi hubungan manusia, yang diisi oleh 67 responden guru, dan 20 pernyataan dengan 4 indikator disiplin kerja guru yang diisi oleh
67 responden guru dan 27 kepala sekolah sebagai evaluator untuk menilai ke-67 responden guru.

Penelitian dilakukan selama satu bulan, dari tanggal 01 s.d 30 November 2016 dengan menyebar kuesioner pada guru dan kepala sekolah SD Negeri di Kecamatan Pagelaran, Kabupaten Pandeglang, Provinsi Banten.

Kuesioner sebelum disebar ke responden di uji validitas dan reliabilitas instrumen dengan menggunakan product moment dan untuk reliabilitas ditentukan dengan koefisien Cronbach Alpha. Teknik analisis data menggunakan statistik dekriptif dan statistik inferensial dengan regresi liner ganda.

Regresi linear ganda untuk mengetahui korelasi antara variabel bebas secara bersamasama dengan variabel terikat. Menurut Riduwan (2014: 154) analisis regresi ganda adalah pengembangan dan analisis regresi sederhana. Kegunaannya adalah yaitu-untuk meramalkan nilai variabel terikat (Y) apabila variabel bebas minimal dua atau lebih.

Menurut Darmadi (2013: 149) analisis regresi adalah analisis yang digunakan untuk mencari bagaimana variabel-variabel bebas dan variabel terikat berhubungan pada hubungan fungsional atau sebab akibat. Persamaan regresi yang berkaitan dengan variabel-variabel yang diteliti adalah sebagai berikut:

$$
\hat{\mathrm{Y}}=\mathrm{a}+\mathrm{b} 1 \mathrm{X}_{1}+\mathrm{b} 2 \mathrm{X}_{2}
$$

Keterangan:

$\hat{\mathrm{Y}}=\quad$ Disiplin kerja guru

$\mathrm{X}_{1}=\quad$ Perilaku kepemimpinan berorientasi tugas

$\mathrm{X}_{2}=\quad$ Perilaku kepemimpinan berorientasi hubungan manusia

$\mathrm{a}=\quad$ Konstanta

b1, b2, = koefisien regresi 


\section{HASIL DAN PEMBAHASAN}

\section{Hasil}

Sehubungan dengan rumusan masalah dan hipotesis penelitian yang diajukan sebagaimana diuraikan pada bagian sebelumnya maka dapat dijelaskan bahwa variabel-variabel yang mempengaruhi disiplin kerja guru (Y) adalah perilaku kepemimpinan kepala sekolah berorientasi tugas $\left(\mathrm{X}_{1}\right)$ dan perilaku kepemimpinan kepala sekolah berorientasi hubungan $\left(\mathrm{X}_{2}\right)$. Dalam penelitian ini variabel terikatnya adalah disiplin kerja guru yaitu variabel Y. Analisis data yang digunakan dalam penelitian ini adalah regresi linear ganda yang digunakan untuk mengetahui seberapa besar terdapat pengaruh secara bersama-sama dari kedua variabel bebas perilaku kepemimpinan kepala sekolah berorientasi tugas $\left(\mathrm{X}_{1}\right)$ dan perilaku kepemimpinan kepala sekolah berorientasi hubungan $\left(\mathrm{X}_{2}\right)$ terhadap variabel terikat disiplin kerja guru (Y). Berdasarkan dari hasil perhitungan pengolahan data melalui bantuan program SPSS 16.0 diperoleh hasil sebagai berikut.

Tabel 1. Hasil Uji Regresi Linier

Ganda

Coefficients $^{\mathrm{a}}$

\begin{tabular}{|l|l|l|l|l|l|l|}
\hline & \multicolumn{2}{|l|}{$\begin{array}{l}\text { Unstandardized } \\
\text { Coefficients }\end{array}$} & $\begin{array}{l}\text { Standardized } \\
\text { Coefficients }\end{array}$ & & \\
\cline { 2 - 6 } Model & $\mathrm{B}$ & $\begin{array}{l}\text { Std. } \\
\text { Error }\end{array}$ & Beta & $\mathrm{t}$ & Sig. \\
\hline 1 & (Constant) & .151 & .339 & & .446 & .659 \\
\hline & $\begin{array}{l}\text { Perilaku } \\
\text { Tugas }\end{array}$ & .859 & .138 & .813 & 6.216 & .000 \\
\hline & $\begin{array}{l}\text { Perilaku } \\
\text { Hubungan }\end{array}$ & .104 & .125 & .109 & .832 & .413 \\
\hline & & & & & & \\
\hline
\end{tabular}

a.DependentVariable: Disiplin Kerja Guru
Correlations

\begin{tabular}{|l|l|l|l|l|}
\hline \multicolumn{2}{|c|}{} & $\begin{array}{l}\text { Disiplin } \\
\text { Kerja } \\
\text { Guru }\end{array}$ & $\begin{array}{l}\text { Perilaku } \\
\text { Tugas }\end{array}$ & $\begin{array}{l}\text { Perilaku } \\
\text { Hubungan }\end{array}$ \\
\hline $\begin{array}{l}\text { Pearson } \\
\text { Correla- } \\
\text { tion }\end{array}$ & Disiplin Kerja Guru & 1.000 & .892 & .693 \\
\cline { 2 - 5 } & Perilaku Tugas & .892 & 1.000 & .718 \\
\cline { 2 - 5 } & Perilaku Hubungan & .693 & .718 & 1.000 \\
\hline \multirow{3}{*}{$\begin{array}{l}\text { Sig. } \\
(1-\text { tailed })\end{array}$} & Disiplin Kerja Guru &. & .000 & .000 \\
\cline { 2 - 5 } & Perilaku Tugas & .000 & & .000 \\
\cline { 2 - 5 } & Perilaku Hubungan & .000 & .000 & \\
\hline \multirow{4}{*}{ N } & Disiplin Kerja Guru & 27 & 27 & 27 \\
\cline { 2 - 5 } & Perilaku Tugas & 27 & 27 & 27 \\
\cline { 2 - 5 } & Perilaku Hubungan & 27 & 27 & 27 \\
\hline
\end{tabular}

Berdasarkan hasil perhitungan pada Tabel 1 coefficients, diperoleh persamaan regresi linear ganda sebagai berikut:

$$
\hat{y}=0,151+0,813 X_{1}+0,109 X_{2}
$$

Variabel perilaku kepemimpinan kepala sekolah berorientasi tugas $\left(\mathrm{X}_{1}\right)$ mempunyai nilai koefisien 0,813 , artinya apabila variabel $X_{1}$ naik satu satuan akan menambah nilai koefisien disiplin kerja guru. Nilai tersebut bernilai di atas nol, artinya bernilai positif sehingga semakin tinggi perilaku kepemimpinan kepala sekolah berorientasi tugas maka akan semakin tinggi juga disiplin kerja guru.

Variabel perilaku kepemimpinan kepala sekolah berorientasi hubungan $\left(\mathrm{X}_{2}\right)$ mempunyai koefsien 0,109 , artinya apabila variabel $X_{2}$ naik satu satuan akan menambah nilai koefisien disiplin kerja guru. Di samping itu, semakin tinggi perilaku kepemimpinan kepala sekolah berorientasi hubungan maka semakin tinggi pula disiplin kerja guru. Tanda positif menunjukan bahwa perilaku kepemimpinan kepala sekolah berorientasi hubungan memiliki pengaruh positif terhadap disiplin kerja guru, jika perilaku 
kepemimpinan kepala sekolah dipersepsikan positif oleh responden maka akan semakin tinggi pula disiplin kerja guru.

\section{Uji Parsial (Uji t)}

Untuk menguji hipotesis digunakan uji t yang menunjukan pengaruh dari masingmasing variabel bebas terhadap variabel terikat. Pada tahapan ini dilakukan pengujian terhadap pengaruh variabel bebas yang terdapat pada model yang terbentuk untuk mengetahui apakah variabel bebas perilaku kepemimpinan kepala sekolah berorientasi tugas $\left(\mathrm{X}_{1}\right)$ dan perilaku kepemimpinan kepala sekolah berorientasi hubungan $\left(\mathrm{X}_{2}\right)$ secara parsial mempunyai pengaruh yang signifikan terhadap variabel terikat $(\mathrm{Y})$. Adapun hasil uji t adalah sebagai berikut.

\section{Pengaruh Perilaku Kepemimpinan Berorientasi Tugas $\left(\mathrm{X}_{1}\right)$ terhadap Disiplin Kerja Guru (Y)}

Tabel 2. Hasil Uji t pada Variabel $X_{1}$ Coefficients $^{\mathrm{a}}$

\begin{tabular}{|l|l|l|l|l|l|}
\hline \multirow{1}{*}{} & $\begin{array}{l}\text { Unstan- } \\
\text { dardized } \\
\text { Coefficients }\end{array}$ & $\begin{array}{l}\text { Standardi- } \\
\text { zed } \\
\text { Coefficients }\end{array}$ & & \\
\cline { 2 - 4 } Model & B & $\begin{array}{l}\text { S t d . } \\
\text { Error }\end{array}$ & Beta & & Sig. \\
\hline $\begin{array}{l}\text { 1 (Constant) } \\
\text { Perilaku } \\
\text { Tugas }\end{array}$ & .217 & .328 & & .663 & .514 \\
.942 & .096 & .892 & 9.844 & .000 \\
\hline
\end{tabular}

a. Dependent Variable: Disiplin Kerja Guru

Dari Tabel 2 pada tabel coefficient diperoleh nilai $\mathrm{t}_{\text {hitung }}=9,844$ lebih besar dari $\mathrm{t}_{\text {tabel }}=2,00$ dengan tingkat sig. 0,000 lebih kecil dari koefisiensi 0,05 artinya perilaku tugas signifikan terhadap disiplin kerja guru dan hipotesis pertama diterima.
Pengaruh Perilaku Kepemimpinan Berorientasi Hubungan Manusia $\left(\mathrm{X}_{2}\right)$ terhadap Disiplin Kerja Guru (Y)

Tabel 3. Hasil Uji t pada Variabel $\mathrm{X}_{2}$

\section{Coefficients $^{\mathrm{a}}$}

\begin{tabular}{|c|c|c|c|c|c|}
\hline \multirow[b]{2}{*}{ Model } & \multicolumn{2}{|c|}{$\begin{array}{l}\text { Unstan- } \\
\text { dardized } \\
\text { Coefficients }\end{array}$} & \begin{tabular}{|l|} 
Standardi- \\
zed Coeffi- \\
cients \\
\end{tabular} & \multirow[b]{2}{*}{$\mathrm{t}$} & \multirow[b]{2}{*}{ Sig. } \\
\hline & B & $\begin{array}{l}\mathrm{Std} . \\
\text { Error }\end{array}$ & Beta & & \\
\hline $\begin{array}{ll}1 \text { (Constant) } \\
\text { Perilaku } \\
\text { Hubungan }\end{array}$ & $\begin{array}{l}1.221 \\
.660\end{array}$ & $\begin{array}{l}.462 \\
.137\end{array}$ & .693 & $\begin{array}{l}2.642 \\
4.801\end{array}$ & $\begin{array}{l}.014 \\
.000\end{array}$ \\
\hline
\end{tabular}

a. Dependent Variable: Disiplin Kerja Guru

Dari Tabel 3 pada tabel coefficient diperoleh $\mathrm{t}_{\text {hitung }}=4,801$ lebih besar dari $\mathrm{t}_{\text {tabel }}$ $=2,00$ dan tingkat signifikansi $=0,000$ lebih kecil dari koefisien 0,05. artinya perilaku hubungan manusia berpengaruh signifikan terhadap disiplin kerja guru dan hipotesis kedua diterima.

\section{Uji Serentak (Uji F)}

Uji F digunakan untuk mengetahui pengaruh fungsi perilaku kepemimpinan kepala sekolah berorientasi tugas $\left(\mathrm{X}_{1}\right)$ dan perilaku kepemimpinan kepala sekolah berorientasi hubungan $\left(\mathrm{X}_{2}\right)$ secara simultan atau bersamasama terhadap disiplin kerja guru (Y).

Tabel 4. Hasil Uji F

\section{Coefficients $^{\mathrm{a}}$}

\begin{tabular}{|c|c|c|c|c|c|}
\hline \multirow[b]{2}{*}{ Model } & \multicolumn{2}{|c|}{$\begin{array}{l}\text { Unstan- } \\
\text { dardized } \\
\text { Coeffi- } \\
\text { cients }\end{array}$} & \multirow{2}{*}{$\begin{array}{l}\begin{array}{l}\text { Standar- } \\
\text { dized } \\
\text { Coeffi- } \\
\text { cients }\end{array} \\
\text { Beta }\end{array}$} & \multirow[b]{2}{*}{$t$} & \multirow[b]{2}{*}{ Sig. } \\
\hline & B & $\begin{array}{l}\mathrm{Std} \\
\text { Error }\end{array}$ & & & \\
\hline 1 (Constant) & .151 & .339 & & .446 & .659 \\
\hline $\begin{array}{l}\text { Perilaku } \\
\text { Tugas }\end{array}$ & .859 & .138 & .813 & 6.216 & .000 \\
\hline $\begin{array}{l}\text { Perilaku } \\
\text { Hubunga }\end{array}$ & .104 & .125 & .109 & .832 & .413 \\
\hline
\end{tabular}

a. Dependent Variable: Disiplin Kerja Guru 


\section{ANOVA $^{b}$}

\begin{tabular}{|ll|l|l|l|c|c|}
\hline & & $\begin{array}{c}\text { Sum of } \\
\text { Squares }\end{array}$ & df & Mean & & \\
& Square & F & Sig. \\
\hline 1 & Regression & 1.712 & 2 & .856 & 48.202 & $.000^{\mathrm{a}}$ \\
& Residual & .426 & 24 & .018 & & \\
& Total & 2.138 & 26 & & & \\
\hline
\end{tabular}

a. Predictors: (Constant), Perilaku Hubungan, Perilaku Tugas

b. Dependent Variable: Disiplin Kerja Guru

Dari Tabel 4 Anova pada tabel coefficient diperoleh nilai $\mathrm{F}_{\text {hitung }}=48,202$ lebih besar dari $\mathrm{F}_{\text {tabel }}=3,14$, maka Ho ditolak dan $\mathrm{Ha}$ diterima, artinya signifikan. Jadi, perilaku kepemimpinan berorientasi tugas dan perilaku kepemimpinan berorientasi hubungan mempunyai pengaruh secara bersama dan signifikan terhadap disiplin kerja guru, dan artinya hipotesis ketiga diterima

\section{Pembahasan}

\section{Pengaruh Perilaku Kepemimpinan Berorientasi Tugas terhadap Disiplin Kerja Guru}

Perilaku kepemimpinan berorientasi tugas mempunyai peranan penting dalam hal mendisiplinkan para guru, karena dengan perilaku ini kepala sekolah bisa menekan para guru untuk melaksanakan tugasnya dengan terstruktur dan sungguh-sungguh. Sebagaimana yang diungkapkan oleh Yukl (2009:79) bahwa perilaku berorientasi pada tugas adalah jenis perilaku terutama memperhatikan penyelesaian tugas, menggunakan personil dan sumber daya secara efisien, dan menyelenggarkan operasi yang teratur dan dapat diandalkan.

Berdasarkan analisis data yaitu variabel perilaku kepemimpinan berorientasi tugas terhadap disiplin kerja guru menunjukan adanya pengaruh yang positif dan signifikan, terlihat dari nilai $t$ hitung yang dihasilkan sebesar 9,844 dengan tingkat signifikan kurang dari 0,05 yaitu 0,00 . Hasil dalam penelitian ini menunjukkan bahwa perilaku kepemimpinan kepala sekolah berorientasi tugas mempunyai pengaruh yang signifikan dalam meningkatkan disiplin kerja guru.

Pengaruh perilaku kepemimpinan kepala sekolah berorientasi tugas $\left(\mathrm{X}_{1}\right)$ terhadap disiplin kerja guru (Y) menunjukan arah positif, ditunjukan dengan nilai koefisien korelasi 0,892 dengan nilai sig 0,00 artinya semakin tinggi perilaku kepemimpinan kepala sekolah berorientasi tugas maka semakin tinggi disiplin kerja guru, terlihat dari hasil uji model summary didapatkan nilai koefisien dterminasi atau $\mathrm{R}_{\text {square }}=0,795$ yang artinya perilaku tugas mempunyai sumbangan pengaruh sebesar $79,50 \%$ terhadap disiplin kerja guru.

Tingginya pengaruh perilaku kepemimpinan berorientasi tugas terhadap disiplin kerja guru SD di Kecamatan Pagelaran dikarenakan guru di kecamatan tersebut masih terpaku pada disiplin kerja dengan selalu menunggu perintah dari atasan, melalui tugas-tugas yang terstruktur dan jelas dengan pantauan dan tekanan, seperti yang dikemukakan oleh Gibson, dkk (1988: 268-270) penelitian di Universitas Michigan yang berpusat pada pekerjaan dan berpusat pada karyawan. Pemimpin yang berpusat pada pekerjaan melakukan pengawasan yang ketat sehingga bawahan menjalankan tugas mereka dengan menggunakan prosedur khusus. Tipe pemimpin ini mendasarkan diri pada paksaan, imbalan, dan kekuasaan yang sah untuk mempengaruhi perilaku dan hasil karya pengikut. Hasil penelitian terhadap perilaku berpusat pada pekerjaan tersebut menunjukan adanya peningkatan 
sebesar 25\% dikarenakan dalam divisi yang dikendalikan secara hirarkis, diasumsikan bahwa tekanan dan perilaku pemimpin yang berpusat pada pekerjaan merupakan sebab kenaikan.

Berdasarkan hasil penelitian baik yang dilakukan maupun hasil penelitian terdahulu ada kesamaan bahwasanya perilaku tugas dapat meningkatkan disiplin kerja dikarenakan adanya tekanan dan tuntutan tugas dengan prosedur khusus dan juga ada paksakan dengan kekuasaan yang sah. Namun, hal itu bisa terjadi dalam waktu yang tidak lama, dikarenakan adanya tekanan dan ketidaknyamanan bawahan dalam hal bertugas.

Perilaku kepemimpinan yang hanya berorientasi tugas dapat mendisiplinkan kerja guru tetapi dapat membuat tekanan dan ketidaknyamanan terhadap guru, sebagaimana diungkapkan oleh Sutrisno (2012: 92) bahwa pemimpin yang kurang baik, yang memakai kekuasaannya dengan sewenang-wenang dan menggunakan ancaman terus menerus, kadang dapat memperoleh apa yang tampak sebagai disipilin yang baik, namun rasa gelisah dan tidak tentram yang timbul dari peraturan yang keras dan paksaan saja, dapat meledak di muka pimpinan setiap waktu.

Para ahli riset berpendapat bahwa hasil ini memberi kesan bahwa organisasi serupa itu pada khususnya memusatkan perhatian pada ukuran efektivitas jangka pendek. Jadi, jika kita hanya melihat pada produksi maka divisi yang dikendalikan secara hirarkis bekerja lebih efektif. Namun, jika diperhatikan juga indikator kepuasan maka keunggulan gaya yang berpusat pada pekerjaan menjadi lemah dan diragukan (Gibson, dkk 1988: 270).

\section{Pengaruh Perilaku Kepemimpinan Berorientasi Hubungan Manusia terhadap Disiplin Kerja Guru}

Perilaku kepemimpinan yang berorientasi pada hubungan antara manusia menekankan pada komunikasi serta membangun dan mempertahankan hubungan yang efektif seperti motivasi, peningkatan kesejahteraan, dan kepuasan para staf/pegawai sehingga tujuan organisasi dapat tercapai.

Berdasarkan hasil perhitungan analisis korelasi antara variabel perilaku kepemimpinan kepala sekolah berorientasi hubungan terhadap disiplin kerja guru, diperoleh nilai koefisien korelasi antara $\mathrm{X}_{2}$ dan $Y$ sebesar 0,693 dengan taraf signfikan 0,000 kurang dari 0,05 yang artinya signifikan. Berdasarkan perhitungan koefisien dterminasi ( $\mathrm{R}_{\text {square}}$ ) diperoleh nilai sebesar 0,480 yang artinya perilaku kepemimpinan berorientasi hubungan manusia berkontribusi sebesar 48,00\% terhadap disiplin kerja guru.

Perilaku kepemimpinan hubungan mempunyai pengaruh yang lebih rendah dibandingkan dengan perilaku tugas, hal ini disebabkan guru-guru SD Negeri di Kecamatan Pagelaran masih terpaku pada tugas-tugas dan perintah atasan, sehingga ketika kepala sekolah tidak membuat suatu kebijakan atau aturan-aturan dengan pantauan dan tekanan maka guru akan menjadi santai dan kurang disiplin, hal ini juga dibarengi oleh rendahnya kepala sekolah memberi pengakuan, memotivasi, kerja sama serta komunikasi terhadap guru.

Perilaku kepala sekolah bisa meningkatkan disiplin kerja guru melalui hubungan manusia yang baik, sebagaimana yang dikemukakan oleh Robbins et al (2015: 250) bahwa seorang pemimpin yang secara efektif 
menampilkan dan mengelola emosinya akan lebih mudah memengaruhi perasaan para pengikut dengan mengekspresikan simpati dan antusiasme yang tulus untuk kinerja yang baik, dan dengan tidak memperlihatkan kemarahan ketika para pekerja gagal dalam melaksanakan pekerjaannya.

Dengan perilaku kepemimpinan ini guru sebagai pegawai merasa dihargai, diperhatikan, kemudian mereka juga akan termotivasi untuk menjalankan semua tugas dan tanggung jawabnya, sehingga tujuan pendidikan dengan guru sebagai ujung tombak akan tercapai, oleh karena itu kepala sekolah dengan perilaku kepemimpinan berorientasi hubungan akan mempengaruhi disiplin kerja guru, dengan perilaku ini kepala sekolah berusaha menjalin komunikasi, kerja sama, memberikan pengakuan, mengembangkan para staf (guru) serta memberikan motivasi. Dengan perlakuan ini disiplin kerja mereka juga akan meningkat, terutama bagi para guru yang selalu ingin mengembangkan diri.

Hasil penelitian menunjukan kontribusi perilaku kepemimpinan berorientasi tugas lebih besar yaitu sebesar 79,50\% jika dibandingkan dengan perilaku kepemimpinan berorientasi hubungan yaitu sebesar 48,00\% terhadap disiplin kerja guru. Namun, perilaku kepemimpinan berorientasi hubungan manusia ini tidak boleh diabaikan karena sesuai dengan kodrat manusia sebagai makhluk sosial maka akan membutuhkan orang lain dan ingin saling menghormati, menghargai baik dalam komunikasi maupun kerja sama. Apabila pemimpin bisa menjadi tauladan dengan perilaku kepemimpinan yang diterapkannya maka staf atau bawahan juga berusaha mengikutinya.

\section{Pengaruh Perilaku Kepemimpinan Berorientasi Tugas dan Hubungan Manusia terhadap Disiplin Kerja Guru}

Berdasarkan hasil perhitungan analisis regresi linear ganda antara $\mathrm{X}_{1}, \mathrm{X}_{2}$ dan $\mathrm{Y}$ diketahui koefisien regresi $\mathrm{F}_{\text {hitun }}=48,202$ dengan taraf siginifikan 0,000 dengan $\mathrm{F}_{\text {hitung }}$ lebih besar dai $\mathrm{F}_{\text {tabe }}$ ini menunjukan hasil yang signifikan antara perilaku kepemimpinan kepala sekolah berorientasi tugas dan hubungan manusia secara bersama-sama terhadap disiplin kerja guru SD Negeri di Kecamatan Pagelaran Pandeglang.

Koefisien korelasi bersama (R) yang dihasilkan sebesar 0,895 menunjukan adanya pengaruh yang sangat kuat antara perilaku kepemimpinan berorientasi tugas dan berorientasi hubungan manusia terhadap disiplin kerja guru. Nilai koefisien determinasi atau $\mathrm{R}_{\text {square }}=0,801$ yang artinya mempunyai pengaruh dan kontribusi sebesar 80,10\% terhadap disiplin kerja guru SD Negeri di Kecamatan Pagelaran Pandeglang.

Hasil penelitian ini menunjukan bahwa perilaku kepemimpinan berorientasi tugas dan berorientasi pada hubungan manusia secara bersama-sama mempunyai pengaruh yang kuat dan signifikan dengan disiplin kerja guru. Berdasarkan teori perilaku kepemimpinan yang efektif untuk mencapai suatu tujuan organisasi adalah kombinasi dari perilaku yang berorientasi pada tugas serta perilaku berorientasi pada hubungan manusia.

Pengalaman dan suasana di lapangan ketika dilakukan penelitian pada 27 Kepala Sekolah Dasar Negeri di Kecamatan Pagelaran terlihat melalui hasil kuesioner dan pengalaman selama bertugas di Kecamatan tersebut, bahwa kebanyakan para kepala 
sekolah mengedepankan perilaku tugas untuk kedisiplinan guru tanpa memahami situasi dan kondisi guru dari sisi hubungan manusia. Padahal menurut Timpe (2002: 387) penting untuk dipahami mengapa bertindak seperti yang dilakukan, tetapi sama pentingnya untuk memahami orang-orang lain. Pengawas yang berpengalaman membentuk suasana dalam departemen tertentu, tetapi para karyawan beragam dan salah satu sasaran pengawas adalah untuk lebih memahami para pekerja sebagai individu sebagai suatu cara untuk mengetahui apa yang diperlukan untuk memotivasi dan menantang mereka.

Perilaku kepemimpinan yang efektif merupakan perilaku yang bisa menempatkan dalam berbagai situasi dan kondisi, seperti yang dikemukakan oleh Robbins et al (2015: 255-256) jika para pengikut tidak mampu dan tidak bersedia untuk mengerjakan suatu tugas maka pemimpin perlu menjelaskan dan memberikan pengarahan secara spesifik, jika mereka tidak mampu tetapi bersedia maka pemimpin harus memperlihatkan orientasi tugas yang tinggi untuk mengompensasikan kekurangan kemampuan dari para pengikutnya, dan orientasi hubungan yang tinggi yang membawa mereka untuk "masuk ke dalam" keinginan dari pemimpin. Jika para pengikut mampu tetapi tidak bersedia maka pemimpin perlu menggunakan gaya kepemimpinan yang suportif dan partisipatif, jika mereka mampu dan bersedia maka pemimpin tidak perlu melakukan upaya.

Dalam penelitian ini perilaku kepemimpinan yang menggabungkan dua perilaku, yaitu perilaku orientasi tugas dan orientasi hubungan manusia mempunyai kontribusi yang paling tinggi terhadap disiplin kerja guru, sesuai pendapat Pidarta
(2005: 197) yang menyebutkan bahwa kepemimpinan yang baik ialah kepemimpinan yang mengintegrasikan orientasi tugas dengan orientasi antar- hubungan manusia. Kedua orientasi ini perlu dipadukan dan kedua-duanya ditingkatkan. Hanya dengan cara ini kepemimpinan akan menjadi efektif, yaitu mampu mencapai tujuan organisasi tepat pada waktunya.

Implikasi dari hasil penelitian ini jelas menunjukan bahwa perilaku kepemimpinan kepala sekolah yang baik merupakan kepemimpinan yang bisa mengkombinasikan perilaku berorientasi tugas dengan berorientasi hubungan manusia. Di samping kepala sekolah mampu memberikan dukungan, memberi pengakuan, memotivasi, kerja sama serta komunikasi, juga mampu memberikan tugas dengan jelas dan tanggung jawab serta selalu memantau para guru dalam menjalankan tugas-tugas yang diberikan sehingga mereka memiliki disiplin kerja yang tinggi dengan harapan dapat memberikan pengetahuan, keterampilan, dan sikap baik pula pada siswa.

Dengan perilaku kepemimpinan yang mengkombinasikan antarorientasi tugas dan hubungan antarmanusia maka para staf dalam hal ini guru merasa diperhatikan baik dalam hal tugas dan kewajiban maupun hak dan kesejahteraan pegawai yang bisa memicu tingkat kedisiplinan guru, sehingga dengan kedispilinan yang baik tujuan pendidikan yang diprogramkan dapat tercapai dengan baik, efektif, dan produktif.

\section{SIMPULAN DAN SARAN}

\section{Simpulan}

Berdasarkan analisis data dan pembahasan hasil penelitian yang telah 
diuraikan sebelumnya maka dapat ditarik simpulan sebagai berikut, bahwa terdapat pengaruh perilaku kepemimpinan kepala sekolah berorientasi tugas terhadap disiplin kerja guru, terdapat pengaruh perilaku kepemimpinan kepala sekolah berorientasi hubungan manusia terhadap disiplin kerja guru, dan terdapat pengaruh yang signifikan antara perilaku kepemimpinan kepala sekolah berorientasi tugas dan perilaku hubungan manusia secara bersama-sama terhadap disiplin kerja guru SD Negeri di Kecamatan Pagelaran, Kabupaten Pandeglang, Provinsi Banten.

\section{Saran}

Berdasarkan hasil penelitian dan simpulan di atas maka dapat diajukan beberapa saran kepada, para Kepala Sekolah Dasar Negeri se Kecamatan Pagelaran, dalam kepemimpinannya agar menerapkan perilaku, baik perilaku berorientasi tugas, perilaku berorientasi hubungan manusia, dan gabungan dari kedua perilaku tersebut karena berpengaruh signifikan untuk meningkatkan disiplin kerja guru.

UPT Dinas Pendidikan dan Pengawas Sekolah, dapat memanfaatkan hasil penelitian ini untuk disosialisasikan kepada para Kepala Sekolah Dasar Negeri yang ada di Kecamatan Pagelaran bahwa perilaku kepemimpinan kepala sekolah dapat memberikan pengaruh untuk meningkatkan kedisipilinan guru.

Bagi mahasiswa atau peneliti, hasil penelitian ini dapat digunakan sebagai studi dan masukan dalam mengkaji lebih lanjut masalah yang berkaitan dengan perilaku kepemimpinan kepala sekolah sebagai upaya meningkatkan disiplin ataupun kinerja guru.

\section{PUSTAKA ACUAN}

Darmadi, Hamid. 2013. Metode Penelitan Pendidikan dan Sosial. Bandung: Penerbit Alpabeta. $\mathrm{Ok}$

Faruq, Umar. 2006. Perilaku Kepala Sekolah dalam Meningkatkan Profesionalisme Guru di SMA Khadijah Surabaya. Tesis. Surabaya: Program Pasca Sarjana Universitas Negeri Surabaya. Ok1

Gibson, L James, Ivancevich, Donnelly. 1988. Organisasi dan Manajemen. Diterjemahkan oleh: Djoerban Wahid, SH. Jakarta: Penerbit Erlangga. Ok

Hafidz, Abdul. 2003. Perilaku Pemimpin Kepala Sekolah (Studi Kasus di SD Ta'miriyah Surabaya). Tesis Surabaya: Program Pasca Sarjana Universitas Negeri Surabaya. Ok.2

Hidayat, Nurul. 2007. Pengaruh Perilaku Kepemimpinan dan Budaya Organisasi Terhadap Kinerja Guru SMU Negeri di Kota Surabaya. Tesis. Surabaya: Program Pasca Sarjana Universitas Negeri Surabaya. Ok3

Indrafachrudi, Soekarto. 1994. Mengantar Bagaimana Memimpin Sekolah yang Baik. Jakarta: Ghalia Indonesia. ok

Mulyasa, E. 2004. Manajemen Berbasis Sekolah: Konsep, Strategi, dan Implementasi. Bandung: Remaja Rosdakarya. ok

Mulyasa, E. 2009. Menjadi Kepala Sekolah Profesional. Bandung: Remaja Rosdakarya. ok 
Murtadlo, M. Ali. 2008. Pengaruh Kepemimpinan Kepala Sekolah terhadap Disiplin Kerja Guru SD di Kecamatan Sumobito. Tesis. Surabaya: Program Pasca Sarjana Universitas Negeri Surabaya. Ok4

Nawawi, Hadari. 2003. Kepemimpinan Mengefektifkan Organisasi. Yogyakarta: Gajah Mada University. ok

Nurhadi, Ali. 2007. Pengaruh Perilaku Kepemimpinan Kepala Sekolah terhadap Disiplin Kerja Guru SDN di Kabupaten Sampang. Tesis. Surabaya: Program Pasca Sarjana Universitas Negeri Surabaya. Ok5

Permadi, Dadi. 2011. Kepemimpinan mandiri (professional) Kepala Sekolah (kiat memimpin yang mengembangakn partisipasi). Bandung: PT. Sarana Panca Karya Nusa. ok

Pidarta, Made. 2005. Perencanaan Pendidikan Partisipatori, dengan Pendekatan Sistem. Jakarta: PT. Rineka Cipta. ok

Pidarta, Made 1995. Peranan Kepala Sekolah pada Pendidikan Dasar. Jakarta: Gramedia Widasarana Indonesia. ok

Rahayu, Sri. Sutama \& Narimo, Sabar. 2014. Kepemimpinan Kepala Sekolah dan Kedisiplinan Guru SMPN Kota Surakarta. Jurnal Manajemen Pendidikan, Vol. 9 No. 2:97-107 ok6

Riduwan. 2014. Metode dan Teknik Menyusun Tesis. Bandung: Alpabeta. ok

Robbins, Stephen P \& Judge, Timothy A. 2015. Perilaku Organisasi (Organizational Behavior). Jakarta: Penerbit Salemba Empat. Ok

Saondi, Ondi \& Suherman, Aris. 2015. Etika Profesi Keguruan. Bandung: PT. Refika Aditama. ok

Soemarmo, D. 1998. Pedoman Pelaksanaan Disiplin Nasional dan Tata Tertib Sekolah. Jakarta: Mini Jaya Abadi. ok

Stoner, James A. F and Freman, Edwar R. 1994. Manajemen. (diterjemahkan oleh Wihelmus dan Benyamin). Jakarta: Intermedia (terbitan asli tahun 1992) ok

Sutrisno, Edy. 2012. Manajemen Sumber Daya Manusia. Jakarta: Prenadamedia Group. ok

Sudharto. 2012. Pengaruh Pola Kepemimpinan Kepala Sekolah dan Suasana Kerja Terhadap Kinerja Guru. Jurnal Manajemen Pendidikan. 1 (2), 212. http://id.portalgaruda.org. ok7

Terek, Edit. 2015. The Impact of Leadership on the Communication Satisfaction of Primary School Teachers in Serbia. Educational Sciences: Theory \& Practice. DOI: 10.12738/ estp.2015.1.2511/?q=leadership +behavior\&pg=6 ok8

Timpe, A. Dale., ed. 2002. Seri Manajemen Sumber Daya Manusia Memimpin Manusia. Terj. Sofyan Cikmat. Jakarta: PT. Elex Media Komputindo, Kelompok Gramedia Anggota IKAPI. ok

Toha, Miftah. 2004. Kepemimpinan dalam Manajemen. Jakarta: PT. Grafindo Persada. ok

Undang - Undang Republik Indonesia No. 20 Tahun 2003. Sistem Pendidikan Nasional. www. kemenag.go.id. Diakses tanggal 6 september 2016. ok

Wahyudi. 2009. Kepemimpinan Kepala Sekolah dalam Organisasi Pembelajar (Learning Organization). Bandung: Alpabeta. ok 
Walker, Jeffrey A. 2009 . The Impact of Principal Leadership Behaviors on the Efficacy of New and Experienced Middle School Teachers. (Desertasi Doktor). Tersedia dari ProQuest Disertations and Theses database (UMI No. 3387319). Ok8

Yuk1, Gary. 2009. Kepemimpinan dalam Organisasi. Jakarta: PT. Macanan Jaya Cemerlang. okWahyudi. 2009. Kepemimpinan Kepala Sekolah dalam Organisasi Pembelajar (Learning Organization). Bandung: Alpabeta. ok

Walker, Jeffrey A. 2009 .The Impact of Principal Leadership Behaviors on the Efficacy of New and Experienced Middle School Teachers. (Desertasi Doktor). Tersedia dari ProQuest Disertations and Theses database (UMI No. 3387319). Ok8

Yukl, Gary. 2009. Kepemimpinan dalam Organisasi. Jakarta: PT. Macanan Jaya Cemerlang. ok 